\title{
Plant-pollinator interactions in Crambe abyssinica Hochst. (Brassicaceae) associated with environmental variables
}

\author{
LÍVIA C. SIMIONI ${ }^{1}$, ROSILDA M. MUSSURY ${ }^{1}$, \\ MUNIR MAUAD ${ }^{2}$, DAIANE M. DRESH ${ }^{2}$, \\ FABRICIO F. PEREIRA ${ }^{1}$ and SILVANA P.Q. SCALON ${ }^{2}$ \\ ${ }^{1}$ Universidade Federal da Grande Dourados. Faculdade de Ciências Biológicas e Ambientais. \\ Programa de Pós Graduação em Entomologia e Conservação da Biodiversidade, \\ Rodovia Dourados-Itahum, Km 12, 79404-070 Dourados, MS, Brasil \\ ${ }^{2}$ Universidade Federal da Grande Dourados. Faculdade de Ciências Agrárias. \\ Rodovia Dourados-Itahum, Km 12, 79404-070 Dourados, MS, Brasil
}

Manuscript received on September 3, 2013; accepted for publication on June 22, 2014

\begin{abstract}
Despite the economic importance of Crambe abyssinica, the present study is the first report on bees that occur with this species, and could aid in developing alternative methods for controlling insect pests without seriously impacting pollinators. The present study examined the following questions: (1) Which species are potential pollinators of $C$. abyssinica? (2) How do environmental conditions influence pollinator visitation fluctuations? Insects were sampled on a weekly basis between 08:00 and 16:00 during five weeks of flowering. When the results of analyses of variance were significant, the data was adjusted using regression equations at a 5\% level of probability; the environmental variables were examined using Pearson's correlation coefficient. Apis mellifera, Geotrigona mombuca, Exomalopsis (Exomalopsis) fulvofasciata, Plebeia sp. and Dialictus sp. were observed visiting C. abyssinica flowers. A. mellifera and G. mombuca were observed to be potential pollinators, with the former demonstrating visitation peaks during flowering weeks II and IV at 12:00 and 08:00, respectively and the latter visiting during weeks III and IV at 12:00 and 10:00, respectively. Environmental factors such as temperature, relative humidity, and wind speed have different effect on the activity of bees.
\end{abstract}

Key words: biodiesel, crambe, associated insects, oleaginous, pollination.

\section{INTRODUCTION}

An analysis of global tendencies during the last 50 years in relation to economically important plants that are dependent or independent of pollinators indicated that there was no support for the

Correspondence to: Rosilda Mara Mussury

E-mail: maramussury@ufgd.edu.br hypothesis that population declines of pollinators had affected global agricultural production (Aizen et al. 2009). These authors acknowledged, however, a disproportional increase in areas planted with crops that depend on pollinators, which has increased the necessity for ecological services furnished by animal pollinators. It has also been demonstrated 
that the presence of pollinators increases the weights of seeds of agricultural crops (Mussury and Fernandes 2000) as well as their commercial value (Bommarco et al. 2012).

As such, knowledge about floral biology and pollination ecology will be extremely important to our understanding of the natural world as well as for commercial crop production. Additionally, studies of the pollinators of commercially valuable species can aid in the production of better quality fruits and seeds (Kearns et al. 1998, Barros et al. 2006, Vaknin 2012).

Social bees of the family Apidae are the most important pollinators of cultivated plants, and these insects depend almost exclusively on the pollen and nectar harvested from the flowers they visit. Apis mellifera Linnaeus (1758) is the most important pollinator of monoculture crops on a global scale, (Watanabe 1994) as these bees can be active throughout the year, pollinate a wide variety of cultures, and can be transported and concentrated in large numbers when necessary. The food industry in developed countries, such as the United States, has noted that as farms increase in size and management techniques become more intense, they tend to depend less on solitary or semi-social bees and more on A. mellifera for pollination services (Morse and Calderone 2000).

A number of studies have surveyed the pollinators of Brassicaceae, including those of rapeseed Brassica napus L. (Willians 1985, Mussury et al. 2003, Jauker and Wolters 2008) and the radish Raphanus sativus L. (Teixeira and Zampierom 2007), however studies of crambe were not encountered in the examined literature.

Crambe (Crambe abyssinica Hochst) belongs to the family Brassicaceae and is utilized as a forage plant, in crop rotations, and in the production of press-cake, and has recently attracted attention for its potential for producing biodiesel. Originally from the Mediterranean region, crambe has been planted in Africa, Asia, Europe, the United States,
Mexico, and South America (Pitol et al. 2010). Crambe flowers are grouped in a raceme type inflorescences; they are apical, cruciform, with a white corolla, tetramerous, hermaphroditic, and actinomorphic. The calyx has four free, greenish sepals, tetramerous, actinomorphic. The stamens are six in number, tetradinamo, stamens free (unattached to each other), with rimose, dorsifixed anthers, introrse, and show longitudinal dehiscence. The green gynoecium has a short style, a papilose stigma, and a superior, unicarpelar ovary, containing a single ovule with apical placentation. The fruit is a capsule.

Studies concerning this species were initiated by the MS Foundation in the state of Mato Grosso do Sul, Brazil, in 1995 to evaluate its behavior in a direct planting system. In spite of its good adaptation to the region, its low costs, and ease of cultivation it did not elicit much initial interest as a cultivar because its dry mass production was inferior to that of the radish and there was no developed market for it. However, due to increased interest in the use of biodiesel, crambe production has reappeared (Pitol et al. 2010). Crambe tolerance to drought, frosts, and precociousness, its short life cycle (between 90 and 100 days) (Oplinger et al. 1991), flowering for 85 to 90 days, and uniform maturation all favor its commercial production.

Various factors influence bee's activities. These factors may be internal, such as colony size and the necessity for natural resources, or external, such as the temperature and relative humidity (Teixeira and Campos 2005). A number of studies have reported correlations between climatic factors and bee activity as evaluated by the number of bees leaving the hive (Balestieri and Machado 1998, Hilário et al. 2000, 2001, 2007a, b, Contrera et al. 2004), or the numbers of bees visiting focal flowers (Williams 1985, Mussury et al. 2003).

Research with economically important plants and studies of insect pollinator diversity are relevant to the large-scale production of vegetable oils since the introduction of these commercially 
valuable plants could affect insect biodiversity and/or adjacent cultures through the introduction of exotic pests and reductions in the populations of locally beneficial species (pollinators, pollenivorous species, and species of conservation/biodiversity interest) (Medan et al. 2011). Research show that the species from Brassicasseae family synthesize by their secondary metabolism a compound named Glucosinolate, which is toxic to generalist insects, that imitate the damages caused by the Herbivorous (Li et al. 2010, Ratzka et al. 2002).

Considering the potential economic importance of crambe, we sought to respond to the following question: (1) Which species are potential pollinators of Crambe abyssinica? (2) How do environmental conditions affect visitation fluctuations of pollinators?

\section{MATERIALS AND METHODS}

The present study was undertaken in 2011 at the Fazenda Experimental da Universidade Federal da Grande Dourados - UFGD, in the municipality of Dourados, state of Mato Grosso do Sul (MS), Brazil (2248'53" S and 54'44’31"; covering approximately 294 ha.).

Crambe Seeds (Brilhante FMS variety) were supplied by the MS Foundation. The crambe crop was established in an area of $490 \mathrm{~m}^{2}$ and divided into four sub-areas.

The culture handling consisted of two manual weeds, one at the $20^{\text {th }}$ and the other at the $40^{\text {th }}$ day of growth. During the growth period, there were no insecticide and fungicide applications.

Insect sampling was performed weekly in 10 randomly chosen sites, starting after the appearance of the first flowers until their total absence. In each spot, scans were performed along the row for about eight meters, using a $30 \mathrm{~cm}$ diameter insect net.

Collections were made every two hours starting at 08:00 until 16:00, totaling five daily sampling events. Previous sampling experiments had demonstrated that bee numbers were much reduced before 08:00 and after 16:00.
The captured individuals were placed in plastic sacks with pieces of cotton containing ethyl acetate and subsequently removed to the entomology laboratory at the Faculdade de Ciências Biológicas e Ambientais da UFGD for counting and identification; the numbers of individuals sampled during the different times of day and during the different weeks during the flowering period of crambe (May and June/2011) were noted.

After identifying the bees, the pollen was removed from their corbicula to determine its origin. The pollen collected from each individual was placed in a drop of water on a slide, covered with a coverslip, and examined under a light microscope. The pollen borne by the insects was compared with pollen collected directly from the floral anthers. The behavior of the insects on the flowers was also observed and their visitation durations recorded.

To describe the flowering stages, the floral buds were analyzed in terms of the numbers of floral parts and their dispositions. The numbers of open flowers on 10 individual plants were counted in the field, as well as the numbers of plants per square meter, and used to estimate the total numbers of flowers open during each week of flowering.

The numbers of insects and open flowers were evaluated using the t-test to determine the flowering and visitation peaks. The data concerning the numbers of insects, the visitation hours during the weeks of flowering, the temperature, relative humidity, and wind velocity were evaluated using Pearson's correlation analysis (Snedecor and Cochran 1989) for the most abundant insects. Meteorological data was obtained from the meteorological station at the Universidade Federal da Grande Dourados in Dourados, MS.

When the results of analysis of variance were significant the data was adjusted using regression equations at a $5 \%$ level of probability using the computer program SANEST. 


\section{RESULTS AND DISCUSSION}

The crambe plants demonstrated a culture cycle of 90 days, and bee visitation was monitored during the entire flowering period.

The following Apoidea bees were collected on crambe flowers: Apis mellifera, Geotrigona mombuca (Smith 1863), Plebeia sp. (Schwarz 1938), Exomalopsis (Exomalopsis) fulvofasciata (Smith 1879) (Apidae), and Dialictus sp. (Robertson 1902) (Halictidae). Crambe pollen was found on the bodies of all of the insects collected, indicating that they visited the flowers and (considering the small sizes of the flowers) probably came into contact with the floral parts while collecting nectar and pollen - and were therefore potential pollinators.

Four floral stages were established, marking three distinct phases: bud (stages 1 and 2) (Fig. 1a and b), anthesis - flower opening - (stage 3) (Fig. 1c), and post-anthesis (stage 4) (Fig. 1d).

During stage 1, the calyx completely covers the bud and the androecium is composed of six short stamens with identical heights whose anthers are closed. Stage 2 is characterized by the opening of the pedals, which extend beyond the calyx. The stamens now demonstrate discrete differences in their heights, although the anthers remain closed. Stage 3 corresponds to anthesis, which occurs with the opening of the petals; the petals alternate with the stamens and the latter are fully differentiated in terms of their sizes (4 long and 2 short); dehiscence of the anthers is longitudinal and introrse. In stage 4 , the flower assumes a darker color and the floral parts begin to wilt.

In spite of the fact that anther dehiscence in crambe flowers is introrse (a characteristic of selfpollinated plants) the reproductive organs are well exposed, which favors cross-pollination. Insects therefore have important roles in the reproduction of $C$. abyssinica and can maximize productivity by increasing fruit and seed production and improving their quality $-\mathrm{a}$ situation that has been observed in other economically valuable cultures such as
Brassica napus L. (Mussury and Fernandes 2000, Mussury et al. 2003, Jauker and Wolters 2008) and Raphanus sativus L. (Teixeira and Zampierom 2007).

Flowering in crambe lasted five weeks, with individual plants having large numbers of flowers (up to 800). Flowering was greatest during weeks III and IV (Fig. 2), with no significant differences being observed in the numbers of flowers during that time $(\mathrm{t}=0.043 ; \mathrm{p}=0.96)$. The largest number of visiting bees was seen during week IV, coinciding with that flowering peak.

These results and in loco observation suggest that the presence of large numbers of insects was due to the abundant pollen and nectar rewards offered by the crambe flowers. Machado and Carvalho (2006) noted that the nectar produced by sunflower plants (an economically important oleaginous species) was important for the attraction and maintenance of pollinators in cultivated areas and also contributed to commercial honey production.

The A. mellifera was observed to be the most abundant between 08:00 and 12:00 (Fig. 3), when average temperatures were between 12 and $21^{\circ} \mathrm{C}$. These insects initiated their foraging activities relatively early, visiting numerous flowers and remaining on each for approximately 2 seconds while collecting pollen; during this time they came into contact with the stigmas. Avila and Marchini (2008) reported that $A$. mellifera represented fully $55.8 \%$ of the bees collected in a fragment of cerradão (Neotropical savanna) vegetation. Rosa et al. (2010) observed the behavior of A. mellifera on $B$. napus (Brassicaceae) flowers and noted that the bees entered into contact with both the anthers and stigmas, and were therefore considered potential pollinators. Rosa et al. (2011) likewise concluded that these same bees were the most frequent pollinators of rapeseed, and recommended introducing colonies of these insects to increase seed production. In their study of $B$. napus, Mussury et al. (2003) noted that the visitation peak of most insect 


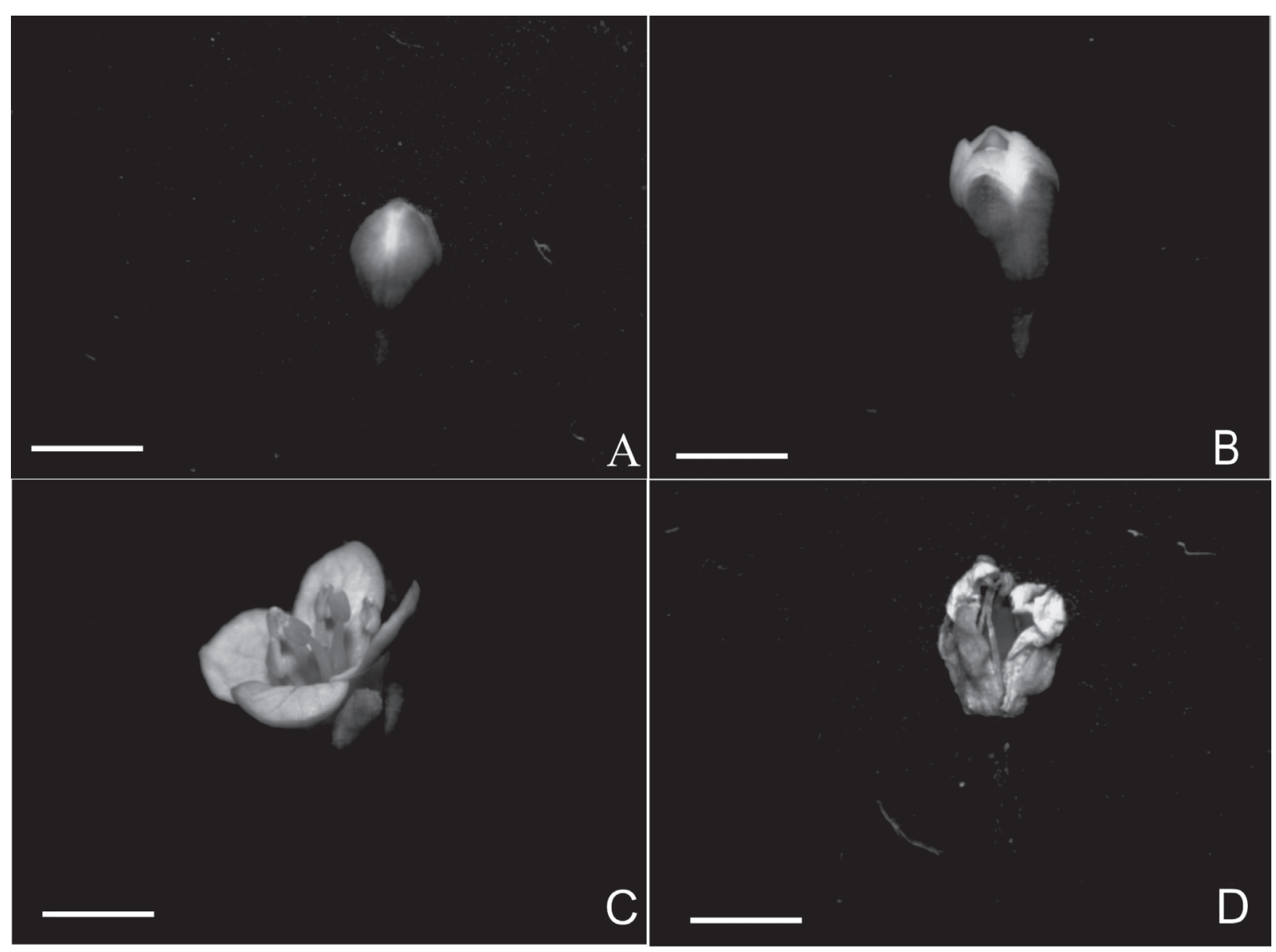

Figure 1 - Floral development of Crambe abyssinica. A and B. bud; C. anthesis; D. post-anthesis. Scale bar $=2 \mathrm{~mm}$

pollinators was between 09:00 and 15:00. Williams (1985) observed that most bee activity on B. napus occurred between 06:30 and 15:00, with most of the pollen being collected between 08:00 and 10:00 probably because of the more favorable temperature and relative humidity at that time of day. As such, the main period of foraging on the different species of Brassicaceae is generally between 08:00 and 10:00.

According to Teixeira and Zampierom (2007), $95 \%$ of the floral visitors to $R$. sativus belong to the family Apidae; of these, $75 \%$ are pollinators, while the rest are nectar pillagers. Apis mellifera always appears as a pollinator and never as a nectar pillager, while representatives of the genus Trigona will pollinate and/or pillage. Neither A. mellifera nor $G$. mombuca were observed pillaging crambe.
Environmental variables influenced bee visitation to crambe in different manners (Table I). We observed that one of the most relevant factors to the appearance of bees on the crambe crop was temperature, which corroborated the studies of Burril and Dietz (1981) and Imperatriz-Fonseca et al. (1985) who reported increases in the dislocation rates of bees as a function of temperature increases. The largest numbers of visiting insects were observed when temperatures were near $21^{\circ} \mathrm{C}$.

During weeks II and III there were slight reductions in the numbers of $A$. mellifera individuals visiting crambe flowers (Fig. 2). The correlation analyses indicated that the relative humidity was responsible for an average of $78 \%$ of this reduction (Table I). 
TABLE I

Pearson's Correlation Values between the sampling times and the weeks of flowering and the numbers of insects collected on crambe flowers in terms of temperature, relative humidity, and wind velocity. Dourados - MS.

\begin{tabular}{|c|c|c|c|c|c|}
\hline \multicolumn{6}{|c|}{ Temperature $\left({ }^{\circ} \mathrm{C}\right) /$ Number of insects } \\
\hline Time & A. mellifera & G. mombuca & Flowering week & A. mellifera & G. mombuca \\
\hline 08:00 & 0.47 & $0.75^{*}$ & $\mathrm{I}$ & 0.17 & -0.004 \\
\hline $10: 00$ & $0.63 *$ & $0.94 *$ & II & 0.31 & 0.60 \\
\hline $12: 00$ & $0.71 *$ & $0.78 *$ & III & 0.01 & 0.45 \\
\hline $14: 00$ & 0.04 & $0.64 *$ & IV & $-0.98^{*}$ & -0.27 \\
\hline $16: 00$ & 0.25 & $0.78^{*}$ & $\mathrm{~V}$ & 0.23 & 0.00 \\
\hline \multicolumn{6}{|c|}{ Relative humidity (\%) / Number of insects } \\
\hline Time & A. mellifera & G. mombuca & Flowering week & A. mellifera & G. mombuca \\
\hline 08:00 & -0.51 & -0.52 & I & -0.13 & 0.04 \\
\hline $10: 00$ & -0.14 & $-0.74 *$ & II & $-0.78^{*}$ & -0.39 \\
\hline $12: 00$ & $-0.88^{*}$ & 0.23 & III & -0.01 & $-0.75^{*}$ \\
\hline $14: 00$ & 0.56 & 0.22 & IV & $0.98^{*}$ & $-0.83^{*}$ \\
\hline $16: 00$ & 0.67 & -0.22 & $\mathrm{~V}$ & -0.27 & 0.00 \\
\hline \multicolumn{6}{|c|}{ Wind velocity $(\mathrm{m} / \mathrm{s})$ / Number of insects } \\
\hline Time & A. mellifera & G. mombuca & Flowering week & A. mellifera & G. mombuca \\
\hline 08:00 & 0.06 & 0.07 & I & 0.003 & -0.37 \\
\hline $10: 00$ & 0.58 & -0.09 & II & 0.61 & 0.51 \\
\hline $12: 00$ & 0.04 & $0.85^{*}$ & III & 0.49 & $0.68 *$ \\
\hline $14: 00$ & 0.04 & 0.66 & IV & $-0.79 *$ & 0.34 \\
\hline $16: 00$ & 0.27 & $0.95^{*}$ & $\mathrm{~V}$ & 0.52 & 0.00 \\
\hline
\end{tabular}

* Correlation significant at a 5\% level of probability.

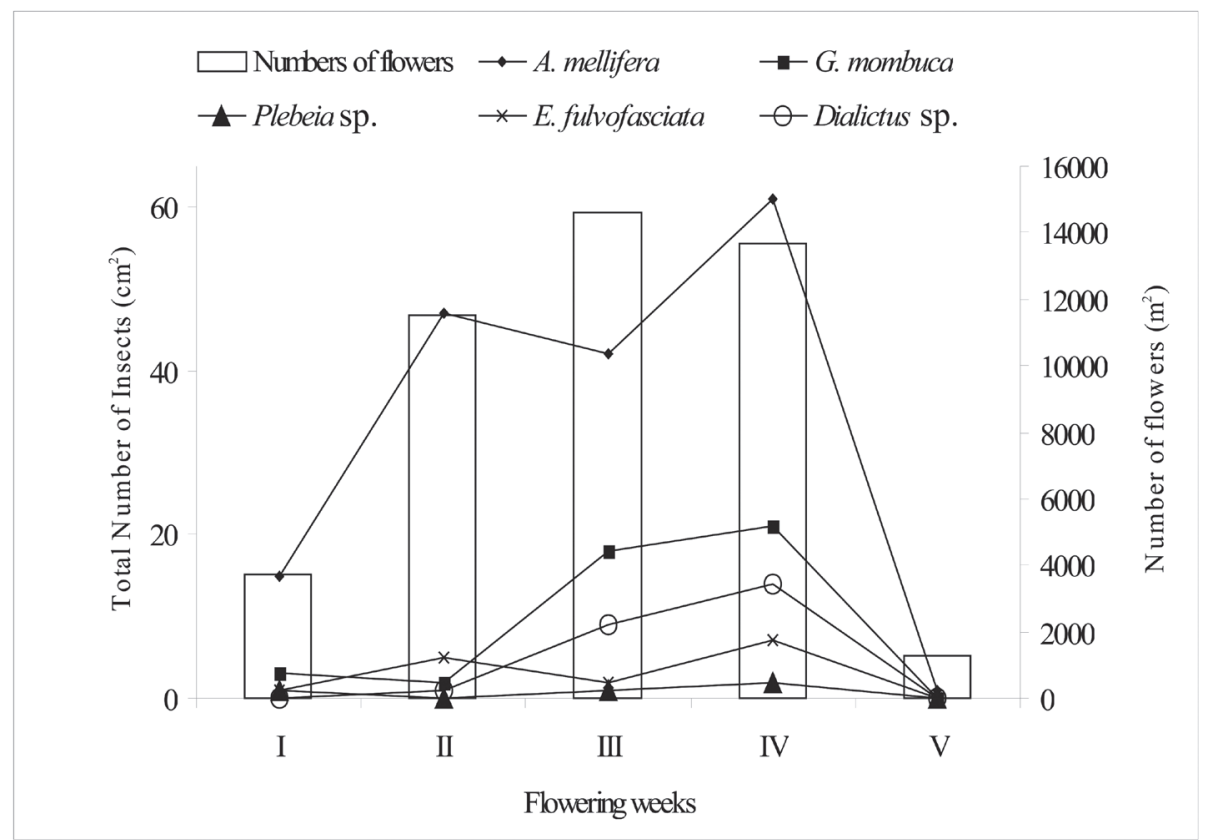

Figure 2 - Fluctuations in the numbers of bees visiting Crambe abyssinica during the different weeks of flowering. 
In relation to the flowering weeks, it was observed that $A$. mellifera visited $C$. abyssinica flowers during the entire flowering period, with peaks during weeks II, III and IV, and with respective peak visiting hours of 12:00, 10:00 and 8:00 (Fig. 3). Teixeira and Zampierom (2007) observed that A. mellifera had visitation peaks to radish flowers near 10:20 when the mean temperature was $25^{\circ} \mathrm{C}$, while Trigona had a visitation peak at 09:30 when the mean average temperature was $22.5^{\circ} \mathrm{C}$. As the temperature between 10:00 and 12:00 during the present study was near $21^{\circ} \mathrm{C}$, this factor positively influenced the numbers of visiting insects. According to Corbet et al. (1993), temperature is the most important environmental factor influencing the external (outside the nest) activities of bees. When the relative humidity was near $45 \%$ at $12: 00$ it negatively influenced (-0.88) floral visitation. No significant correlation was observed between wind velocity and $A$. mellifera activity.

The G. mombuca was also observed throughout the flowering period of crambe, with greater numbers of these bees being seen during flowering weeks III and IV (Fig. 2). It can be seen in Table I that the low relative humidity negatively (near $44 \%$ ) influenced visitation by this insect.

In relation to the numbers of individuals of $A$. mellifera visiting C. abyssinica flowers, maximum visitation peaks were observed during weeks II and IV at 12:00 and 08:00 respectively (Fig. 3A). However, after week III of flowering there were significant reductions in the numbers of visiting insects, mainly after 12:00. Large numbers of individuals of G. mombuca were observed during weeks III and IV, although at distinct times of the day (12:00 and 10:00 respectively) (Fig. 3B).

A positive correlation was observed between environmental temperatures and insect visitation between 08:00 and 16:00. Relative humidity was significantly negatively correlated with visitation at 10:00. Wind velocity was significantly positively correlated with visitation at 12:00 and 16:00 (Table I).
There were sharp decreases in the numbers ofopen flowers of $C$. abyssinica after week IV of flowering. The Meliponini Plebeia sp., E. fulvofasciata, and Dialictus spp appeared in very low numbers during all of the flowering stages. Very reduced numbers of flowers were available during week V, and floral senescence was observed together with the initiation of fruit maturation, with consequent decreases in the frequency of floral visitations by insects.

Williams (1985) and Mussury et al. (2003) observed that the greatest numbers of pollinators visiting $B$. napus occurred when there were large numbers of flowers undergoing anthesis and when environmental conditions were favorable, in agreement with the results of the present study. $A$. mellifera appears to be the main potential pollinator of crambe as it initiates foraging activities earlier than the other bee species and therefore takes greater advantage of available floral resources. It was also observed that environmental factors influence bee's activities differently. The reproductive organs of $C$. abyssinica flowers are well exposed, which favors cross-pollination when pollen is the main resource used by pollinators. Thereby, the potential role of the bees in the Crambe's pollination results in an increased production.

The present study is the first report on the floral visitors of $C$. abyssinica, and could aid in developing alternative methods for controlling insect pests, whenever necessary, without seriously impacting pollinators.

Considering the importance of conserving the pollinators, data generated by this research clarifies the pollinator's activity and therefore helps with the correct application of pesticides. According to Pinheiro and Freitas (2010) and Freitas and Pinheiro (2012) pesticides cause a decrease in the diversity and quantity of pollinators in agroecosystems and if applied during cold season they cause greater risk, due to remaining in the environment for long periods. The basic issue is to find the products that present a lower risk to pollinators or choose 
A

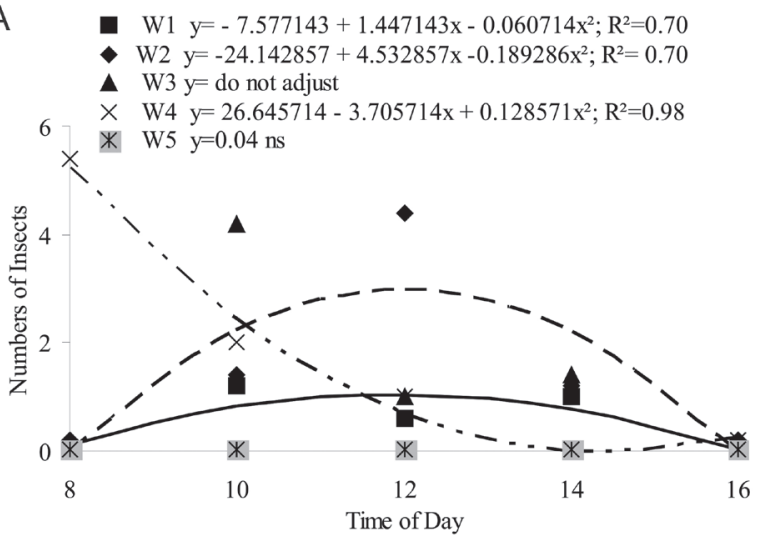

B

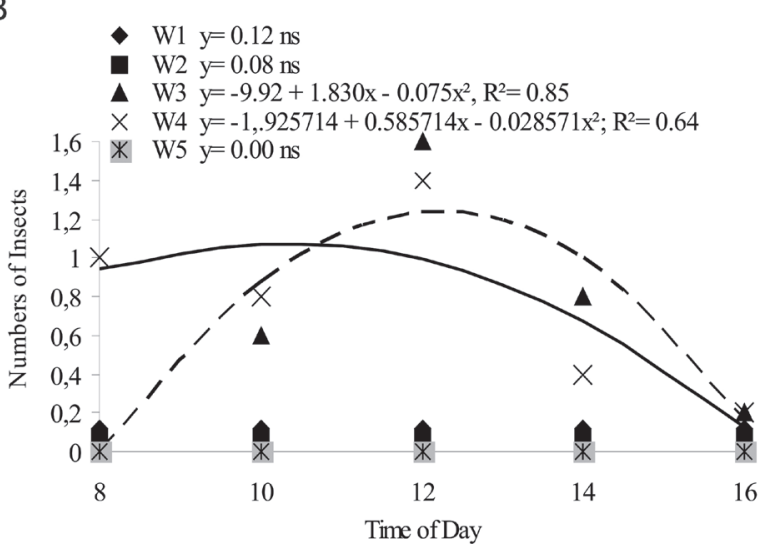

Figure 3 - Numbers of individuals of Apis mellifera (A) and Geotrigona mombuca (B) observed visiting Crambe abyssinica L. during of the flowering weeks and time of day.

formulations that are less toxic to pollinators, which with Crambe was during the period between 8 a.m and 16 p.m, and avoid its application in the flowering period or opt for night applications or even applications on the ground.

\section{ACKNOWLEDGMENTS}

The authors would like to thank Professor Dr. Fernando A. Silveira from UFMG for identifying the bees, and Professors Valter Vieira Alves Junior and Fátima Cristina De Lazari Manente Balestieri from UFGD for their valuable suggestions to this paper. The authors are also grateful to Conselho Nacional de Desenvolvimento Científico e Tecnológico (CNPq) for the scholarship concession to the first author and FUNDECT for the financial support.

\section{RESUMO}

Considerando a importância econômica de Crambe abyssinica, o presente estudo é o primeiro relato das abelhas ocorrentes na espécie representando contribuição para a Ciência, pois permite adequar métodos alternativos de controle para outros insetos daninhos com menor impacto aos polinizadores. O objetivo do presente trabalho foi responder as seguintes questões: (1) qual é a espécie polinizadora potencial em C. abyssinica? (2) como as condições ambientais interferem na flutuação populacional dos polinizadores? Os insetos foram amostrados semanalmente, com rede entomológica, das 8 às 16 horas durante cinco semanas de florescimento. $\mathrm{O}$ delineamento experimental foi inteiramente casualizado em esquema fatorial $5 \times 5$ (horário $\mathrm{x}$ semanas de florescimento). Havendo significância na análise de variância, os dados foram ajustados por equações de regressão à $5 \%$ de probabilidade e para as variáveis ambientais por correlação de Pearson. Foram observados Apis mellifera, Geotrigona mombuca, Exomalopsis (Exomalopsis) fulvofasciata, Plebeia sp. e Dialictus sp. Observou-se que o polinizador potencial é $A$. mellifera apresentando pico máximo de visitas na II e IV semana de florescimento as 12:00 e 8:00 horas respectivamente e G. mombuca nas semanas III e IV as 12:00 e 10:00 horas respectivamente. Os fatores ambientais como temperatura, umidade relativa e velocidade do vento interferem de forma diferenciada na atividade das abelhas.

Palavras-chave: biodiesel, crambe, insetos associados, oleaginosa, polinização.

\section{REFERENCES}

AIZEN MA, GARIBALDI LA, CUNNINGHAM SA AND KLEIN AM. 2009. How much does agriculture depend on pollinators? Lessons from long-term trends in crop production. Ann Bot 103: $1579-1588$

Avila M AND Marchini LC. 2008. Análise faunística de himenópteros visitantes florais em fragmento de cerradão em Itirapina, SP. Cienc Florest 18: 271-279.

BALESTIERI FCML AND MACHADO VLL. 1998. Entomofauna visitante de sibipiruna (Caesalpinia peltophoroides Benth.) durante o seu período de floração. Rev Bras Entomol 41: 547-554. 
Barros R, Degrande PE, Ribeiro JF, Rodrigues ALL, NogueIRA RF AND FERnANDES MG. 2006. Flutuação Populacional De Insetos Predadores Associados A Pragas Do Algodoeiro. Arq Institut Biol 73: 57-64.

Bommarco R, MARINI L AND VAISSIÈRE BE. 2012. Insect pollination enhances seed yield, quality and market value in oilseed rape. Oecologia 169: 1025-1032.

BURRIL M AND DIETZ A. 1981.The response of honeybees to variation in solar radiation and temperature. Apidologie 12: 319-328.

CONTRERA FAL, IMPERATRIZ-FONSECA VL AND NIEH JC. 2004. Temporal and climatological influences on flight activity in the stingless bee Trigona hyalinata (Apidae, Meliponini). Rev Tecnol Amb 10: 35-43.

Corbet SA, Fussell M, AKe R, Fraser A, Gunson C, SAVAge CAND SMITH K. 1993. Temperature and pollination activity of social bees. Ecol Entomol 18: 17-30.

Freitas BM AND PINHEIRO JN. 2012. Efeitos sub-letais dos pesticidas agrícolas e seus impactos no manejo de polinizadores dos agroecossistemas Brasileiros. Oecologia Australis, 14: 282-298.

HILÁRIO SD, IMPERATRIZ-FONSECA VL AND KLEINERT AMP. 2000. Flight activity and colony strength in the stingless bee Melipona bicolor bicolor (Apidae, Meliponinae). Rev Bras Biol 60: 299-306.

HILÁRIO SD, IMPERATRIZ-FONSECA VL AND KLEINERT AMP. 2001. Responses to climatic factors by foragers of Plebeia pugnax Moure (In litt.) (Apidae, Meliponinae). Rev Bras Biol 61: 191-196.

HILÁRIO SD, RIBEIRO MF AND IMPERATRIZ-FONSECA VL. 2007a. Impacto da precipitação pluviométrica sobre a atividade de vôo de Plebeia remota (Holmberg, 1903) (Apidae, Meliponini). Biota Neotropica 7: 135-143.

HILÁRIO SD, RIBEIRO MF AND IMPERATRIZ-FONSECA VL. 2007b. Impacto do vento sobre a atividade de vôo de Plebeia remota (Holmberg, 1903) (Apidae, Meliponini). Biota Neotropica 7: 225-232.

IMPERATRIZ-FonseCA VL, KLEINERT-GIOVANINI A AND PIRES JT. 1985. Climate variations influence on flight activity of Plebeia remota Holmberg (Hymenoptera, Apidae, Meliponinae). Rev Bras Entomol 29: 427-434.

JAUKER F AND WOLTERS V. 2008. Hover flies are efficient pollinators of oilseed rape. Oecologia 156: 819-823.

KEARNS CA, INOUYE DW AND WASER NM. 1998. Endangered mutualisms: the conservation of plant-pollinator interactions. Ann Rev Ecol System 29: 83-112.

Li X, Ahlman A, YAN X, Lindgren H AND ZHU LH. 2010. Genetic transformation of the oilseed crop Crambe abyssinica. Plant Cell Tissue Organ Cult 100: 149-156.

MACHADO CS AND CARVALHO CAL. 2006. Abelhas (Hymenoptera: Apoidea) visitantes dos capítulos de girassol no recôncavo baiano. Cienc Rural 36: 1404-1409.
MEdAN D, TORRETA JP, HOdARA K, FUENTE EB AND MONTALdO NH. 2011. Effects of agriculture expansion and intensification on the vertebrate and invertebrate diversity in the Pampas of Argentina. Biodivers Conserv 20: 3077-3100.

Morse RA AND CALDERONE NW. 2000. The value of honey bees as pollinators of U.S. crops in 2000. Bee culture magazine 128: 1-15.

MusSURY RM AND FERNANDES WD. 2000. Studies of the floral biology and reproductive system of Brassica napus L. (Cruciferae). Braz Arch Biol Technol 43: 111-117.

Mussury RM, FERnANDES WD AND SCALON SPQ. 2003. Atividade de alguns insetos em flores de Brassica napus L. em Dourados-MS e a interação com fatores climáticos. Cienc Agrotec 27: 382-388.

Oplinger ES, Oelke EA, KAMINSKi AR, PUtnAm DH, Teynor TM, Doll JD, Kelling KA, Durgan BR AND NOETZEL DM. 1991. Crambe: alternative field crops manual. St. Paul: University of Minnesota. Available from: September, p. 3.

PinheIro JN AND Freitas BM. 2010. Efeitos letais dos pesticidas agrícolas sobre polinizadores e perspectivas de manejo para os agroecossistemas brasileiros. Oecologia Australis 14: 266-281.

Pitol C, Broch DL And Roscoe R. 2010. Tecnologia e produção: Crambe 2010. Maracaju: Fundação MS, 60 p.

RatzKa A, Vogel H, KLIEBEnstein DJ, Mitchell-OldS T AND KROYMANN J. 2002. Disarming the mustard oil bomb. Proc Natl Acad Sci 99: 11223-11228.

Rosa AS, Blochtein B, Ferreira NR AND Witter S. 2010. Apis mellifera (Hymenoptera: Apidae) as a potential Brassica napus pollinator (cv. Hyola 432) (Brassicaceae), in Southern Brazil. Braz J Biol 70: 1075-1081.

Rosa AS, Blochtein B AND Lima DK. 2011. Honey bee contribution to canola pollination in Southern Brazil 2011. Scientia Agricola 68: 255-259.

SNEDECOR GW AND COCHRAN GW. 1989. Statistical methods. Iowa: State University, $491 \mathrm{p}$.

TEIXEIRA LV AND CAMPOS FNM. 2005. Início da atividade de vôo em abelhas sem ferrão (Hymenoptera: Apidae): influencia do tamanho da abelha e da temperatura ambiente. Rev Bras Zoociencias 7: 195-202.

TEIXEIRA LMR AND ZAMPIEROM SLM. 2007. Estudo da Biologia Floral e Entomofauna Associada ao Nabo Forrageiro (Raphanus sativus: Cruciferae): Resultados Prévios. Rev Bras Biociências 5: 135-137.

VAKNIN Y. 2012. The significance of pollination services for biodiesel feedstocks, with special reference to Jatropha curcas L.: a rewiew. Bioenergy research 5: 32-40.

WATANABE ME. 1994. Pollination worries rise as honey bees decline. Science 265: 1170.

WILLIAMS IH. 1985. The polinization of swede rape (Brassica napus L.). Bee World 66: 16-20. 
